УДК 130.3

KBT $87.3(4 / 8)$

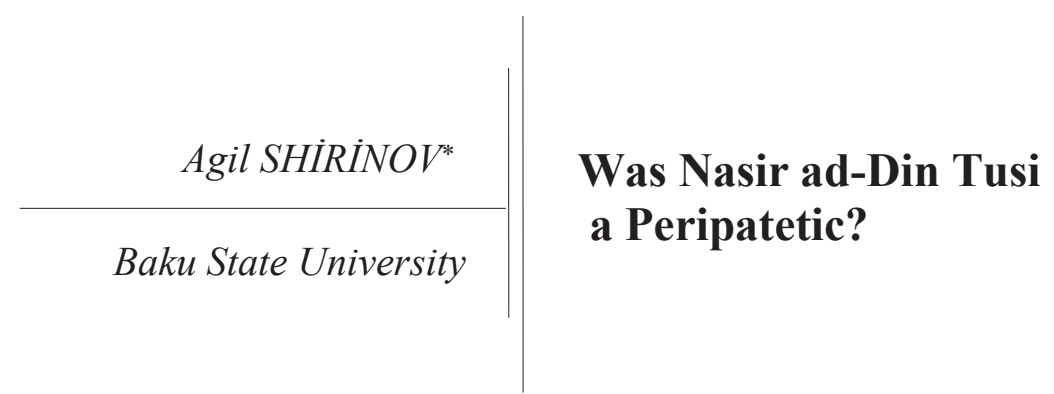

Abstract

Nasir al-Din al-Tusi is accepted by a number of historians of philosophy as a peripatetic philosopher who followed Avicenna. The main claim of this article is that the above-mentioned view does not fully reflect the truth. Namely, it is a fact that in a number of his works, such as Musari al-Musari and Sharh al-Isharat, Tusi defended Avicenna against Asharite theologians Abu al-Fath al-Shahristani and Fakhr al-Din al-Razi. However, he wrote a number of books, such as Tajrid alI'tiqad and Fusul, where he criticized some aspects of Avicenna's thought. Considering the abovementioned facts, it could be claimed that Tusi s thought system is a synthesis of kalamic and peripatetic traditions.

Keywords: Nasr ad-Din Tusi, Avicenna, Emanation, Sharh Al-Isharah, Fusul, Tajrid, Existence, God

\title{
Introduction
}

In the history of philosophy, Nasir al-din al-Tusī has been usually considered as a peripatetic philosopher ${ }^{1}$ who followed Avicenna. This view has some objective reasons. Namely, al-Tusī wrote a commentary on Avicenna`s famous work al-Isha-

\footnotetext{
* İlahiyyat üzrə fəlsəfə doktoru, dosent.

${ }^{1}$ What I mean by peripatetics are al-Farabi, Avicenna and their followers. I exclude here Averroes and non-Muslim peripatetics who had special peripatetic systems which differed from those of al-Fārābī and Avicenna.
} 
rat wa-al-tanbihat (Remarks and Admonitions) and defended him against the prominent Ash'arite scholar, Fakhr al-Dīn al-Rāzī. He also wrote his Musari al-Musari (Struggling with the struggling) against Muhammad ibn 'Abd al-Karim alShahrastani's Kitab al-Musara 'a (Struggling with the Philosopher), which was the criticism of Avicenna's views, and tried to prove the weaknesses of al-Shahristani's arguments. There are also a number of treatises written by al-Tusī in peripatetic style.

Considering al-Tusī's abovementioned activities, some researchers of his thought accepted him as a loyal representative of the peripatetic philosophy. Our main thesis is that this approach does not wholly reflect al-Tusī’s thought system. By being based on abovementioned works, claiming that al-Tusī was a loyal peripatetic who followed Avicenna in his all teaching, is not other than one-sided reading of al-Tusī's thought. In fact, al-Tusī was also one of the most outstanding representatives of the Medieval Islamic theology (kalam). He is considered as one of the founders of the post-Gazali period kalam tradition known as mutaakhkhirun (the later period). Tajrid al-Itiqad, which is his major theological work, is a clear example of his activities in this field. More than 200 commentaries have been written on this book by the scholars of the different kalam schools. It shows, in turn, how important is al-Tusī in kalam tradition.

For determining al-Tusī`s thought tradition, it is important to look at his main philosophical and philsophico-theological works as well as to his views on the major points of disagreement between peripatetic and kalam traditions.

\section{The Peripatetism of al-Tusī}

It is undeniable that the most famous and influential philosophical work of al-Tusī is Sharh al-Isharat. This book is considered as one of the greatest explanations of al-Isharat wa-al-tanbihat, where Avicenna put forward his views on logic, physics and metaphysics. The commentary was written by al-Tusī in 644/ 1256, while he was in the castle of Nizari Ismai'lis. From the explanations of the author at the end of the book, we learn that the book was written in hard times. After praising Avicenna and his book at the beginning of the book, al-Tusi touches on Fakh al-din al-Razi`s critical commentary on Avicenna`s abovementioned work. al-Razi, he says, wrote a commentary to explain the views of Avicenna, but nevertheless he overstepped the bounds of criticism in his book and for this very reason some 
people accepted al-Razi`s work as a severe criticism (jarh-injury) rather than commentary (sharh). Whereas, for al-Tusī, it is necessary for commentators to pull out all the stops to explain the purpose of the author; in this case he will not be a critique but a commentator. If a commentator encounters a view in the text, which cannot be put into the right direction, then he can justly express his dissatisfaction. It means that for al-Tusī, the work of commentators is not to criticize the author of the book that they comment, but their work is to explain what the author means by what is said. al-Tusī also emphasizes that he will be in conformity with this rule in his commentary. ${ }^{1}$

Indeed, he obeys the rule while expounding the text, and even in cases when he does not agree with Avicenna he reminds readers of the term that he has put forward at the beginning of the book and tries to explain what Avicenna means. ${ }^{2}$ Considering this fact, it could be said that the approach, which considers al-Tusī as a peripatetic only by being based on Sharh al-Isharat, is simply wrong.

For us, al-Tusī`s philosophical- theological works, like Tajrid and Fusul, are the main sources for determining his views on the controversial issues between peripatetic and kalam traditions. For, in these books, he is neither a commentator as he is in Sharh al- Isharat, nor a critique as he is in Musari al-Musari and Talkhis alMuhassal as well as he is not a transponder of different views like he is in Qawaid al-Aqaid. In these abovementioned works, he clearly puts forward his own views on different subjects and tries to prove them. Considering all these, it is possible to regard the two works, in particular Tajrid, as the core works of al-Tusīs thought.

$\mathrm{He}$ departs in these works from the peripatetic tradition in a number of issues, such as the theory of emanation (sudur), which has an important place in Avicenna's thought. In Tajrid, he assumes a sceptical attitude on this theory. At the same time, he is very critical of it in Fusul. For his deduction in Fusul, the acceptance of emanation leads us to accept that one of any two beings should be, directly or indirectly, the cause of another one. For the theory of emanation makes it necessary for all beings to be in one chain. Thus, all beings should be, directly or indirectly, related to one another because of the causal link between them. However, it does not correspond to what we see in the sensory world. In addition, for al-Tusī, the multiplicity that exists in the first intelligence is either existential (wujudi) or

\footnotetext{
${ }^{1}$ Sharh al-Isharat, published by Karim Fayzi, Qom, 1383, vol. 1, pp. 75-77.

${ }^{2}$ Ibid, vol. 3, p. 331.
} 
nonexistential (adami). If it is existential then two options are possible: this multiplicity has emanated either from God, therefore from the One, or it has emanated from one other than God, then the necessary being should not be one but many. In case it is non-existential then it should be accepted that the non-existential multiplicity has an effect upon existential ones, and this is, in turn, impossible.

By putting forward the impossibility of all these options, al-Tusī deduces that the theory of emanation is incorrect. ${ }^{1}$ Although he rejects Emanationism in Fusul, his undecided attitude towards this theory in Tajrid as well as his defence of it in his treatise Risala fi Isbati al-'aql al-mufariq (the treatise on the proof of the separated intellect) $)^{2}$ show that he does not reach a final conclusion on this subject. In his correspondences with Sadr ad-Din Qunawi, al-Tusī emphasizes the difficulty of the above-mentioned problem ${ }^{3}$ as well as in his letter to Shams al-Din Khosrowshahi he acknowledges that he could not have solved the problem of how the multiplicity-the universe was generated from the One, which is unitary. ${ }^{4}$

As is known, one of the controversial subjects between peripatetic and kalam traditions is the conception of God. Kalam scholars accepted God as a freely choosing agent (al-fail al-mukhtar) and peripatetics, in turn, as a necessitating cause (mujib). In his kalam works al-Tusī defends the kalam conception of God. For him, it is impossible for the effect of a necessitating cause to be after its cause, and this, in turn, necessitates either the pre-eternity of the universe or the after-existence of the cause. For the reason that they lead to infinite regress (tasalsul) both options are impossible.

At the result, al-Tusī comes to a conclusion that the creator of the universe is

\footnotetext{
${ }^{1}$ See. Fusul, published by Abdullah Nimat, Beirut, 1986, p. 65; Abdallah Nimat, al-Adilla al-Jaliyya, pp. 67-72; al-Suyuri al-Hilli, al-Anvaru al-Jalaliyya fi Sharh al-Fusul alNasiriyya, published by Ali Hadi Abadi-Abbas Jalali Niya, Mashad, 1420/1999, pp. 81 $82 /$

${ }^{2}$ See. Risala fi Isbat'l- 'aqli’l-mufariq, within Talkhis al-Muhassal, Beirut, 1985/1405, pp. 479-481

${ }^{3}$ al-Tusī, Ajvebat Masaili Sadr al-Din al-Qunawi, within Ajvebat Masail al-Nasiriyya, published by Abdullah Nurani, Tehran, 1383, pp. 230-232.

${ }^{4}$ Masail Nasir al-Din al-Tusī an Shams al-Din al-Khosrowshahi, within Ajvebat Masail alNasiriyya, published by Abdullah Nurani, Tehran, 1383, p. 268; This letter later on was responded by Mulla Sadra. See. Mulla Sadra, Ajvebat Masail al-Nasiriyya, within Majmua Rasail Sadr al-Mutaallihinin, published by Hamid Naji Isfahani, Tehran, 1375, pp. 171177.
} 
a freely choosing agent. ${ }^{1}$ However, unlike other kalam scholars, like Fakhr al-Din al-Razi ${ }^{2}$, he does not claim that Avicenna and other peripatetic philosophers do not accept God's omnipotence as a freely choosing agent. He claims that peripatetics do not completely dismiss the conception of freely choosing agency. For al-Tusī, 'the omnipotent (al-qadir) is one who is free to act, or, not to act towards bringing things into existence'. The omnipotent chooses one of two options (to create, and vice versa) when will (irada) is added to power (qudra). Peripatetic philosophers, he claims, do not reject this notion and they accept God's omnipotence in this sense. Furthermore, philosophers accept the free will of God, though they explain it differently from theologians. For them, every agent who acts with his own will is a freely choosing agent. ${ }^{3}$ The main difference between peripatetics and mutakallims (kalam scholars) lays in the possibility or the necessity of creation. That is to say, does the act of creation become necessary if the above-mentioned attributes become together? For the reason that Avicenna and other peripatetics accepted God as a necessitating cause, they defended the notion of necessary creation. For mutakallims, in turn, God is free to create or not create; He is under no obligation, and creation is not necessary but contingent on God's free choice and will. ${ }^{4}$ Moreover, by force of their above-mentioned notion, peripatetics claimed the pre-eternity of the universe (qidam). Kalam scholars, in turn, advocated the conception of the createdness and newness of the universe (huduth al-'alam) and creation ex nihilo 5 .

By expressing that 'nothing else is eternal except $\operatorname{God}^{6}{ }^{6}$ al-Tusī seems to be inclined to accept the kalam notion. At the same time, by saying 'time is not considered important in true eternity and newness' he accepts the notion of essential eternity (al- qidam al-dhati) not temporal eternity (al- qidam al-zamani), and this is, in turn, an attempt towards reconciling the Avicennian Peripatetic conception with that of kalam tradition. Namely, Avicenna also accepts that the universe is created in terms of essence (dhat).

\footnotetext{
${ }^{1}$ Tajrid, published by Muhammad Javad Husaini Jalali, Qom, 1407/1986, p. 191; Ibn Mutahhar Hilli, Kashf al-Murad fi Sharh Tajrid al-I'tiqad, published by Hasan Hasanzadeh Amuli, Qom, 1425, pp. 393-394

${ }^{2}$ See al-Rāzī, Muhassal, tr. Huseyin Atay, Ankara, 2002, p. 164.

${ }^{3}$ Qavaid al-Aqaid, within Talkhis al-Muhassal, Beirut, 1985/1405, p. 445; Sharh alIsharat, Vol. 3, p. 98/

${ }_{5}^{4}$ Qavaid al-'Aqaid, p. 445.

${ }^{5}$ Talkhis al-Muhassal, Beirut, 1985/1405, pp. 269-270.

${ }^{6}$ Tajrid, p. 120
} 
Another separation point between the two above-mentioned traditions is 'God's knowledge of particular material things'. It was written in some medieval kalam books that for the philosophers (Farabi, Avicenna and their followers), God, because of His simplicity, knows particular things according to their universal attributes within Him, accordingly, he does not know them particularly. So, did Avicenna really claim that? Although al-Tusī severely criticizes Avicenna in this very subject in Fusul, in Sharh al-mas 'alat 'l-ilm (the commentary of the problem of knowledge) he claims Avicenna has been misunderstood. For him, the beings which depend on time and space need the internal and external senses for cognizing things. Thus they cognize changings exactly when they happen and they also judge about their existence and non-existence as well as about other characteristics that appear within the frame of time and space. As to a being, who does not depend on time and space, His way of cognition is universal (kulli) and includes the knowledge of all things. He knows when a thing comes to existence as well as $\mathrm{He}$ is aware of the time interval between it and other things before and after its existence. However, unlike the beings, which are dependent upon time and space, He does not judge that a thing that existed before no longer exists. It means God does not judge about the past or present states of things. Al-Tusī gives an interesting example for the elucidation of this issue. He says: 'think of a person who reads the list of books. He will read the list, of course, by following and seeing the sequential letters. But let us think of one who keeps the same list folded. His attribution to all letters is equal. Furthermore, because he possesses the whole list he is aware of what it does include. Nothing big or small is out of his knowledge. al-Tusī quotes here the following verse from the Qur'an: `And with Him are the keys of the unseen; none knows them except Him. And He knows what is in the land and the sea. Not a leaf falls but that He knows it. And no grain is there within the darkness of the earth and no moist or dry [thing] but that it is [written] in a clear book' [the sura of al-An'am-the cattle, 6:59]. For al-Tusī, the peripatetic philosophers put forward this notion for establishing the transcendence of God (al-tanzih). That is to say, just as we say God knows testable, smellable and tactile things, but because of His transcendence we do not say that $\mathrm{He}$ is one who tastes, smells and 
touches, likewise, by saying He knows particular things (juz i) universally (kulli), we absolve Him from the organic cognition. ${ }^{1}$

In his correspondence with Sadr al-Din al-Qunawī and al-Bayarī, al-Tusī comes up with similar conclusion in the issue in question. For him, it is a misunderstanding of their views to claim that the philosophers accept 'God is not cognizant of particular things and events '. Moreover, it is not possible in their thought systems to put forward such claims, because they accept the principle 'the knowledge about cause necessitates the knowledge about effect'. ${ }^{2}$ Avicenna's similar explanations of this issue in al-Isharat ${ }^{3}$ verifies al-Tusī's views.

\section{Conclusion}

In conclusion, it could be said that al-Tusī takes an eclectic approach towards the separation points between Muslim-peripatetic philosophy and kalam tradition. Therefore, it would be a wrong attitude to claim that he was a peripatetic philosopher who followed Avicenna in all his views. His thought system seems to be reconciliation between the two abovementioned thinking traditions.

\section{Bibliography}

Al-Hilli, Ibn Mutahhar, Kashf al-Murad fi Sharh Tajrid al-I tiqad, published by Hasan Hasanzadeh Amuli, Qom, 1425

Al-Rāzī, Fakhr al-Din, Muhassal, tr. Husain Atay, Ankara, 2002

Al-Suyuri al-Hilli, Miqdad b. Abdallah, al-Anvaru al-Jalaliyya fi Sharh alFusul al-Nasiriyya, published by Ali Hadi Abadi-Abbas Jalali Niya, Mashad, $1420 / 1999$

Al-Tusī, Nasir al-Din, Sharh al-Isharat, published by Karim Fayzi, Qom, 1383, vol. 1

\footnotetext{
${ }^{1}$ Sharh al-Mas'alat al-Ilm, , within Ajvebat Masail al-Nasiriyya, pp. 97-100.-

${ }^{2}$ Ajvebat Masail Sadr al-Din al-Qunawi, within Ajvebat Masail al-Nasiriyya, Tehran, 1373, pp. 232- 233; Sharh al-Isharat, vol. 3, pp. 335-338; Ajvebat Masail Fakh al-Din Muhammad ibn Abdallah Bayari, within Ajvebat Masail al-Nasiriyya, pp. 44-46.

${ }^{3}$ See. Avicenna, al-Isharat wa-al- Tanbihat, tr. Ali Durusoy, Muhittin Macit, Ekrem Demirli, İstanbul , 2005, pp. 166-167; see also Avicenna, at-Ta'liqa, Qom, 1421, pp. 27 28.
} 
-------, Ajvebat Masail Fakh al-Din Muhammad ibn Abdallah Bayari, within Ajvebat Masail al-Nasiriyya, published by Abdallah Nurani, Tehran, 1383

, Ajvebat Masail Sadr al-Din al-Qunawi, within Ajvebat Masail alNasiriyya, Tehran, 1383

, Ajvebat Masaili Sadr al-Din al-Qunawi, within Ajvebat Masail alNasiriyya, published by Abdalluh Nurani, Tehran, 1383

-------, Masail Nasir al-Din al-Tusi an Shams al-Din al-Khosrowshahi within Ajvebat Masail al-Nasiriyya, published by Abdullah Nurani, Tehran, 1383

------, Qavaid al- 'Aqaid, within Talkhis al-Muhassal, Beirut, 1985/1405. $1985 / 1405$

, Risala fi Isbat'l- 'aqli'l-mufariq, within Talkhis al-Muhassal, Beirut,

-------, Sharh al-Mas'alat al-Ilm, , within Ajvebat Masail al-Nasiriyya, Tehran, 1383. 1407/1986.

--------, Talkhis al-Muhassal, Beirut, 1985/1405

Beirut, 1986.

, Fusul, within al-Adilla al-Jaliyya published by Abdullah Nimat,

Avicenna, Husain ibn Abdallah, al-Isharat wa-al- Tanbihat, tr. Ali Durusoy, Muhittin Macit, Ekrem Demirli, İstanbul , 2005

---------, at-Ta'liqa, Qom, 1421

Mulla Sadra, Muhammd ibn Ibrahim, Ajvebat Masail al-Nasiriyya, within Majmua Rasail Sadr al-Mutaallihin, published by Hamid Naji Isfahani, Tehran, 1375.

Nimat, Abdallah, al-Adilla al-Jaliyya, Beirut, 1986.

Aqil Şirinov

\section{Nəsirəddin Tusi Peripatetik idimi?}

(xülasa)

Nasiraddin Tusi bir çox falsafo tarixçisi tərafindən İbn Sinanın ardicıl olan peripatetik bir filosof kimi qabul edilir. Bu maqaladə qeyd olunan görüşün həqiqati tam manası ila aks etdirmadiyi iddia olunur. Bela ki, Tusinin başda MusariulMusari va Şərh al-Işarat olmaqla İbn Sinanı Obul-Fath Şəhristani va Foxraddin 
Metafizika - Cild 1, Say 1 (2018)

Razi kimi aşari kəlamçılarının hücumlarına qarşı müdafiə etdiyi asərlarinin mövcudluğu bir faktdır. Lakin eyni zamanda onun başda südur nəzəriyyəsi olmaqla İbn Sina düşüncasinin bazi önəmli ünsürlarina şübha ila yanaşdlğ̆ va ya radd etdiyi Tacrid al-E`tiqad va Fusul kimi asarlari da mövcuddur. Qeyd olunan faktlardan çıxlş edərək Tusinin düşüncə sisteminin kəlam və peripatetik anənələrini özündə ehtiva edən eklektik bir struktura sahib olduğunu iddia etmək mümkündür.

Açar sözlor: Nasiraddin Tusi, İbn Sina, Südur, Şərh al-İşarat, Füsul, Tacrid, Varlıq, Tanrı

\section{Агиль Ширинов}

\section{Являлся ли Насиррадин Туси перипатетиком? (резюме)}

Многие историки философии считают Насираддина Туси философомперипатетиком, последователем Ибн Сины. В статье представлена точка зрения, альтернативная вышеизложенному воззрению. Так, очевидным фактом является существование таких произведений во главе с такими важными сочинениями как Мусари ал-Мусари и Шарх ал-Ишарат, в которых отражаются нападки на Ибн Сину таких ашаритских мутакаллимов, как Абуль Фатха Шахрастани и Фахраддина Рази. В то же время, он является автором таких сочинений, как Таджрид ал-Э 'тигад и Фусул, в которых он выражает сомнение в отнотении некоторых компонентов воззрений Ибн Синь и, особенно, теории эманации (судур) или же, отвергает их. Исходя из указанных фактов, можно утверждать, что в основе системы воззрений Н.Tyси находилась эклектическая структура, включавшая в себя традиции калама и перипатетизма.

Ключевые слова: Насреддин Туси, Ибн Сина, судур, Шарх ал-Ииарат, Фусул, Таджрид, бытие, бог 